\title{
Selecting a Monetary Indicator: A Test of the New Monetary Aggregates
}

\author{
R. W. HAFER
}

HE Federal Reserve System changed its approach to implementing monetary policy on October 6, 1979. Prior to that date, it attempted to reduce fluctuations in short-run interest rates as a means of achieving, along with interest rate stability, a degree of control over movements in the monetary aggregates. On October 6 , however, the Federal Reserve shifted its focus from movements in short-run interest rates to movements in reserves held by the banking system. Shortly thereafter, in early 1980, the Federal Reserve announced major redefinitions of the monetary aggregates.

The shift in operating procedures and the change in the monetary definitions points up the need to investigate which of the new monetary aggregates is the best indicator of monetary actions. Selecting the appropriate aggregate as an indicator requires that several issues be addressed. The first issue concerns the controllability of a given monetary aggregate. In other words, given a change in monetary actions, which aggregate will respond to that change in a predictable manner? A second issue concerns the predictability of the movements in the indicator and ecomomic activity, i.e., how well the monetary aggregate explains movements in a measure of economic activity such as nominal GNP. Finally, there is the important question of the proposed indicator's exogeneity with respect to the economic variable that policymakers are attempting to infuence. This article will examine the last issue, that of exogeneity, using the new monetary aggregates.

\section{ENOGENETTY TESTS}

A monetary indicator is a variable that signals the current direction of monetary policy. Thus, movements in the indicator must not be influenced unduly by, or result from changes in, some non-policy action; that is, the indicator must be exogenous to (not caused by) non-policy actions. ${ }^{1}$ If monetary policymakers attempt to control nominal GNP, for example, changes in GNP should be a direct result of changes in monetary actions as evidenced by changes in the monetary indicator; the monetary indicator must not be directly influenced by changes in GNP. In this sense, a monetary aggregate can be used as an indicator only if movements in GNP do not result in movements in the monetary aggregate.

Previous investigations into the selection of an appropriate monetary indicator have focused primarily on the predictability of the relationship between the hypothesized indicator and nominal income. Friedman and Meiselman, for example, regressed nominal GNP on various measures of money, concluding that $\mathrm{M} 2$ (currency, demand and time deposits) was the preferable definition. ${ }^{2}$ Along these same lines, Schadrack examined the relationship between GNP and six different monetary measures, also concluding that $\mathrm{M} 2$ was statistically superior. ${ }^{3}$ Levin provided another

\footnotetext{
An unresolved debate exists conceming the appropriateness of the term indicator. In some instances, the characteristics used here to denote an indicator have also been used to characterize targets of policy actions. In this article the term indicator lescribes a variable that points to the current direction of monetary policy. To appreciate the complexity of the issues surrounding discussions of "targets" and "indicators" of honetary policy, see Karl Bumner and Alan Meltzer, "The Meaning of Monetary Indicators," Monelary Economics: Readings on Current lssues, ed. William $\mathrm{E}$. Gibson and Gearge $\mathrm{C}$ Katifnan (Now York: McGraw-Hill, 1971 ), pp. 403-15; Kar Brunier, ed. Targets and Indicators of Monetary Policy (Sam Francisco: Chardiler Publishing Co. 1969); Beniamin $A$. Friedman, "Targets, Instruments, and Indicators of Monebary Policy," Journal of Monetary Economics (October 1975), pp. 443-73.

Milton Friedman and David Meiselman, "The Relative Stability of Monetary Velocity and the Investment Multiplier in the United States, $1897-1958, "$ in Commission on Money and Gredit, Stabilization Policies (Englewood Cliffs PrenticeHall, 1963), pp. 165-268.

3 rederick C. Schadrack, "An Empirical Approach to the Definition of Money," Monetary Aggregates and Monetary polucy (Federal Reserve Bank of New York, 1974), pp. 28-34.
} 
test procedure in which changes in GNP are regressed on current and lagged changes of various money and credit aggregates using the Almon lag technique. ${ }^{4}$ In addition to regressing GNP on the different monetary measures, he estimated the relationships using fiscal variables and strike dummies as additional explanatory variables. Based on in- and out-of-sample results, Levin concluded that bank credit should be used as a monetary indicator.

In contrast, Hamburger explicitly tested for the exogeneity of several monetary variables. ${ }^{5} \mathrm{He}$ did this by regressing the different monetary variables on current and lagged values of GNP and the Treasury bill rate. Based on these tests, Hamburger concluded that nonborrowed reserves is a better indicator of policy actions than the other monetary variables studied. Recently, Carlson and Hein also have addressed the issue of selecting a monetary indicator. ${ }^{6}$ Their tests, using the new M1A, M1B and M2 definitions of money, provide a useful examination of the predictive relationship between these money measures and GNP. Their study also provides evidence about the statistical exogeneity of these measures with respect to GNP using tests designed to detect simultaneous equation bias in the estimated regressions.

The focus of this article is to test directly for the exogeneity of the new monetary aggregates with respect to GNP. Nominal GNP is the measure of economic activity traditionally used in studies of this kind. Moreover, there is evidence to suggest that the influence of monetary actions is channeled directly to the economy via nominal GNP. The tests utilized in this article are based on the works of Granger and Sims. ${ }^{7}$

\footnotetext{
"Fred J. Levin, "The Selection of a Monetary Indicator: Some Further Empirical Evidence," Monetary Aggregates and Monetary Policy (Federal Reserve Bank of New York, 1974), pp. $35-39$.

"Michael J. Hamburger, "Indicators of Monetary Policy: The Arguments and the Evidence," American Economic Review, Papers and Proceedings (May 1970), pp. 32-39. The monetary measures used by Hamburger include effective nonborrowed reserves, total reserves, old $\mathrm{M}$, old $\mathrm{M} 2$ and bank credit.

"Keith M. Carlson and Scott E. Hein, "Monetary Aggregates as Monetary Indicators," this Review (November 1980), pp. $12-21$.

TSee C.W.. Granger, "Investigating Causal Relations by Econometric Models and Cross-Spectral Methods" Econometrica (July 1969), pp. 424-38; C.W.J. Granger and Paul Newhold "The Time Series Approach to Econometric Model Building," New Methods in Bustness Cucle Reseatch Proceedings from a Conference (Federal Reserve Bank of Minneapolis, 1977), pp. $7-21$; Christopher A. Sims, "Money, Income, and Caus"lity," American Economic Review (September 1972), pp. 540-52 and "Exogeneity and Causal Ordering in Macroeconomic Models," in New Methods, pp. 23-43.
}

\section{Granger Test}

Granger's test procedure is based on the following premise: if forecasts of some variable $\mathrm{Y}$ (say, GNP) obtained using both past values of $\mathrm{Y}$ and past values of another variable $X$ (say, money) are better than forecasts obtained using past values of $\mathrm{Y}$ alone, then $\mathrm{X}$ is said to "cause" $\mathrm{Y},{ }^{8}$ This causal ordering between two variables is analogous to the ordering between economic activity and certain leading indicators. ${ }^{9}$

Although Granger's test is founded on the notion of causation, it is nevertheless well adapted to determine exogeneity. Suppose, for example, it is shown that changes in GNP "cause" changes in money in Granger's sense. The consequence of this obviates the use of money as an indicator of monetary actions since the policymaker can not differentiate between movements in money due to current changes in policy from those due to changes in GNP. Based on the criteria for selecting a monetary indicator set forth above, the discovery that GNP "causes" money indicates that money is not exogenous to GNP. Consequently, it is not a viable indicator of monetary actions.

To test for Granger causality, it is assumed that the information relevant to the prediction of the respective variables is contained solely in the data series $\mathrm{X}$ and $\mathrm{X}$ (e.g., GNP and money). ${ }^{10}$ Granger's test

8More formally, Granger causality may be defined in the following manner. Let $\mathrm{P}(\mathrm{t})(\mathrm{Y}) \mathrm{U})$ be the optimal, tumbiased prediction of the variable $Y$ given that all relevant information $U$ accumulated since period $t-I$ is known. Using this predietion, the relevint error series $\varepsilon(t)$ is defined as $\varepsilon(t)(Y) U)$ $=\mathrm{Y}(\mathrm{t})-\mathrm{P}(\mathrm{t})(\mathrm{Y} \mid \mathrm{U})$. The variance of the error series is represented by $\sigma^{2}(Y \mid U)$. To say that some variable $X$ "causes" $Y$ in Granger's sense requires that the variance of the error terns - the forecast error variance based on all relewant information - is less than the forecast error variance with in information set that does not inclede $\mathrm{X}$, In other words, if $(\mathrm{U}-\mathrm{X})$ is the information set excluding the data tmbodied in $X$, then Granger causality may be clefined in the following manner:

$$
\begin{gathered}
\text { If } \sigma^{2}(\mathrm{Y} \mid \mathrm{U})<\sigma^{2}(\mathrm{Y} \mid \mathrm{U}-\mathrm{X}) \\
\text { then } \mathrm{X} \text { is said to cause } \mathrm{Y} \text {. }
\end{gathered}
$$

It should be noted, however, that satisfying the above cri terion is a necessary but not sufficient condition to conclude that tridirectional causation ruming from $X$ to $Y$ exists. "Bidirectional causation" or feedback from one variable to another may also exist. Feedback ocours if the conditions $\sigma^{2}(\mathrm{Y} \mid \mathrm{U})<\mathrm{o}^{2}(\mathrm{Y} \mid \mathrm{U}-\mathrm{X})$ and $\sigma^{2}(\mathrm{X} \mid \mathrm{U})<\sigma^{2}(\mathrm{X} \mid \mathrm{U}-\mathrm{Y})$ occur simultaneously. Wher this result emerges, catsation is said to run both from $X$ to $Y$ and from $Y$ to $X$.

"Paul A. Pautler and Richard 1. Rivard, "Choosing a Monetary Aggregate: Causal Relationship as a Criterion," Review of Business and Economic Research (Fall 1979), pp. 1-18.

${ }^{10}$ It is further assuned that the time series $\mathrm{X}$ and $\mathrm{Y}$ are stationary, i.e., the stochastic processes generating the observed $X s$ and $Y_{\text {s }}$ have respective means and variances that are in variant with respect to time. 
then consists of estimating the equations

(1) $X(t)=\sum_{j=1}^{n} \alpha_{j} X(z-j)-\sum_{j=1}^{311} \beta_{j} Y(t-j)+\varepsilon_{t}$

and

(2) $Y(t)=\sum_{j=1}^{\mathrm{m}} \gamma_{j} X(t-j)+\sum_{j=1}^{\mathrm{n}} \delta_{j} X(t-j)+\eta_{t}$.

It is assumed that in estimating these two equations the error series $\varepsilon(t)$ and $\eta(t)$ are uncorrelated. ${ }^{11} \mathrm{On}$ the basis of estimating equations 1 and 2 , unidirectional causation from variable $\mathrm{X}$ to $\mathrm{Y}$ is implied if the estimated coefficients on the lagged $X$ variable in equation 2 are statistically different from zero as a group and the set of estimated coefficients on the lagged $Y$ variable in equation $I$ is not statistically different from zero. Conversely, unidirectional causation from $\mathrm{Y}$ to $\mathrm{X}$ exists if the coefficients on lagged $\mathrm{Y}$ in equation 1 are statistically non-zero as a group and the set of the lagged $X$ 's coefficients is zero in equation 2. Feedback (bidirectional causation) from $\mathrm{Y}$ to $\mathrm{X}$ exists when the set of the coefficients on lagged $Y$ in equation 1 and on lagged $\mathrm{X}$ in equation 2 are statistically different from zero.

\section{Sims Test}

The causality/exogeneity test procedures proposed by Sims also are used to examine the relationship between GNP and the new monetary aggregates. Basically, the notions of Granger causality and statistical exogeneity are equivalent if all of the estimated "future" coefficients $\hat{\alpha}_{\mathfrak{i}}(\mathbf{i}=-\mathrm{m}, \ldots,-1)$ are jointly zero in the equation

(3) $Y(t)=\sum_{i=-1}^{n} \alpha_{1} X(t-i)+\mu(t)$,

where $\mu(t)$ is a white noise residual.12 If $\hat{\alpha}_{1}=0$ for all $\mathrm{i}(\mathrm{i}=-\mathrm{m}, \ldots,-1)$, then " $\mathrm{Y}$ does not cause $X$ " and " $\mathrm{X}$ is exogenous to $\mathrm{Y}$ " are equivalent.

The test procedure proposed by Sims involves regressing current values of the variable $\mathrm{Y}$ on past, current and future values of $X$ and testing the significance of the coefficients on the future Xs. If the coefficients on the future values of $\mathrm{X}$ are not statistically significant as a group, then $\mathrm{X}$ is exogenous to $\mathrm{Y}$. Thus,

11 More specifically, it is assumed that $E[\varepsilon(t), E(s)]=0$, $\mathrm{E}[\eta(\mathrm{t}), \eta(\mathrm{s})] \stackrel{ }{=} 0$ and $E[\varepsilon(\mathrm{t}), \eta(\mathrm{s})]=0$, for all $\mathrm{t} \neq \mathrm{s}$.

12 Equation 3 is based on the assumption that the $Y$ and $X$ time series are jointly covariance-stationary. In other words, the covariance of $Y$ and $X$ are invariant with respect to time, See C.W.I. Granger and Paul Newbold, Forecasting Economic Time Series (New York: Academic Press, 1977). regressing current values of the various monetary aggregates on past, current and future values of GNP provides additional evidence about the exogeneity between GNP and each of the new monetary aggregates. Moreover, regressing current values of GNP on current, past and future values of the different monetary measures allows us to test for the possibility of bidirectional causation. ${ }^{13}$

\section{Empinical Results}

Quarterly observations of the logarithms of nominal GNP and the monetary aggregates M1A, M1B, M2, M3 and $L$ are used to test for exogeneity. ${ }^{14}$ Because the monetary measures are available only since 1959 and because lagged variables must be used in conducting the tests, the empirical results reported are based on the sample period III/1961-IL/1980. Even though seasonally adjusted data are used, seasonal dummy variables are included in all regressions as a precaution against residual seasonality.

The Granger-test regressions are reported in table 1. Each regression includes four lagged observations of the dependent variable and eight lags on the independent variable. The Granger test requires the data to exhibit stationary characteristics, a requirement satisfied by entering a linear trend variable in the regressions. ${ }^{1 \overline{5}}$

13The implementation and interpretation of the Granger and Sins tests are subject to several caveats, For example, in establishing causality, the use of a specific set of variables necessitates that causality statements be made only with reference to the relative information set. In other words, if the information set consists solely of the variables $\mathrm{X}$ and $\mathrm{Y}$, causality is defined only relative to this infornation. This problem has been explored more fully by Jacobs, et al, who argue that tests of the type proposed by Sims are really tests of "informativeness," not econometric exogeneity.

Another problem that may influence the outcome of these tests is the observation period over which the data are reported. For eximple, while test results using annul data may imply unidirectional cansation from $X$ to $Y$, feedback between the two variables may result when data for shorter time periods are used.

Finally, if should be stressed that the information provided by these tests is necessary for exogeneity between two variables. If the test results indicate that future coefficients of the independent variable in equation 3 are significantly different from zero, or that the coefficients on the "independent ${ }^{x}$ variables in equations 1 and 2 fulfill the required conditions, then exogeneity is possible. See Rodney L. Jacobs, Edward E. Eeamer, and Michael P. Ward, "Difficulties with Testing for Causation," Economic Inquiry (1uly 1979), pp. $401-13$.

14 For a description of the new monetary aggregates and how they compare to the old measures, see $K$. W. Hafer, "The New Monetary Aggregates," this Review (February 1980), pp. $25-32$.

10This approach also is employed by Thomas Sargent" "A Classical Macroecononic Model for the United States," Journal of Political Econony (April 1976), pp. 207.37. 
Table 1

Regression Results for the Granger Test

Regression Tested $Y(t)=\sum_{j=1}^{B} \alpha(i) Y(t-1)+\sum_{i=1}^{B} \beta(j) \times(t-1)+\varepsilon_{t}$

Sample Period, II/ $1961-11 / 1980$

F-statistic on all $\beta(j)$

\begin{tabular}{|c|c|c|c|c|c|c|c|c|c|c|c|c|c|c|c|c|}
\hline$Y$ & $x$ & $\alpha(1)$ & $\alpha(2)$ & $\alpha(3)$ & $\alpha(4)$ & $\beta(1)$ & $\beta(2)$ & $\beta(3)$ & $\beta(4)$ & $\beta(5)$ & $\beta(6)$ & $\beta(7)$ & $\beta(8)$ & SE $\times 10^{-3}$ & $\mathrm{DW}$ & $F_{(s, p)}$ \\
\hline GNP & MTA & $\begin{array}{r}0.916 \\
(6.33)\end{array}$ & $\begin{array}{r}-0.089 \\
(0.46)\end{array}$ & $\begin{array}{c}0.078 \\
(0.41)\end{array}$ & $\begin{array}{l}0.056 \\
(0.40)\end{array}$ & $\begin{array}{r}0609 \\
(2,75)\end{array}$ & $\begin{array}{r}0357 \\
(096)\end{array}$ & $\begin{array}{r}0.202 \\
(0.51)\end{array}$ & $\begin{array}{l}0.802 \\
(2.06)\end{array}$ & $\begin{array}{l}0.781 \\
(2.01)\end{array}$ & $\begin{array}{l}-0,437 \\
(1,05)\end{array}$ & $\begin{array}{l}-0.181 \\
(0.45)\end{array}$ & $\begin{array}{r}0,280 \\
(1,33)\end{array}$ & 8.18 & 196 & 2.49 \\
\hline GNP & $M 1 B$ & $\begin{array}{r}0.933 \\
(6.45)\end{array}$ & $\begin{array}{l}0.092 \\
(0.48)\end{array}$ & $\begin{array}{c}0.061 \\
(0.32)\end{array}$ & $\begin{array}{l}0.026 \\
(0,19)\end{array}$ & $\begin{array}{r}0,551 \\
(2,39)\end{array}$ & $\begin{array}{l}0.277 \\
(0.70)\end{array}$ & $\begin{array}{l}0.141 \\
(0,32)\end{array}$ & $\begin{array}{l}-0.853 \\
(2.03)\end{array}$ & $\begin{array}{r}0,778 \\
(1,85)\end{array}$ & $\begin{array}{l}-0.368 \\
(0.84)\end{array}$ & $\begin{array}{r}-0.155 \\
(0.38)\end{array}$ & $\begin{array}{r}0.268 \\
(1.25)\end{array}$ & 8.20 & 1,96 & 243 \\
\hline GNP & $\mathrm{M} 2$ & $\begin{array}{r}0.847 \\
(6.16)\end{array}$ & $\begin{array}{l}-0.111 \\
(0.61)\end{array}$ & $\begin{array}{l}0.044 \\
(0.25)\end{array}$ & $\begin{array}{r}-0,052 \\
(0,42)\end{array}$ & $\begin{array}{l}0.521 \\
(2,66)\end{array}$ & $\begin{array}{l}-0,493 \\
(1,15)\end{array}$ & $\begin{array}{r}0.482 \\
(0.96)\end{array}$ & $\begin{array}{r}-0.891 \\
(1.74)\end{array}$ & $\begin{array}{l}0.903 \\
(1.74)\end{array}$ & $\begin{array}{r}-0.399 \\
(0.76)\end{array}$ & $\begin{array}{r}0.136 \\
(0.30)\end{array}$ & $\begin{array}{r}0.021 \\
(0.10)\end{array}$ & 7,67 & 194 & 384 \\
\hline GNP & M3 & $\begin{array}{l}1.023 \\
(7.46)\end{array}$ & $\begin{array}{l}-0.194 \\
(1,02)\end{array}$ & $\begin{array}{l}0.070 \\
(0.38)\end{array}$ & $\begin{array}{l}-0.018 \\
(0.14)\end{array}$ & $\begin{array}{l}0.364 \\
(1.86)\end{array}$ & $\begin{array}{l}-0.212 \\
(0.50)\end{array}$ & $\begin{array}{r}-0,062 \\
(0,13)\end{array}$ & $\begin{array}{l}-0.415 \\
(0.87)\end{array}$ & $\begin{array}{l}1,161 \\
(2.42)\end{array}$ & $\begin{array}{r}-1.333 \\
(2.67)\end{array}$ & $\begin{array}{r}0762 \\
(170)\end{array}$ & $\begin{array}{r}-0,153 \\
(0.74)\end{array}$ & 7.99 & 1.89 & 296 \\
\hline GNP & $L$ & $\begin{array}{r}0.907 \\
(6.67)\end{array}$ & $\begin{array}{l}0.168 \\
(0.92)\end{array}$ & $\begin{array}{r}0.016 \\
(0.09)\end{array}$ & $\begin{array}{l}-0.001 \\
(0.00)\end{array}$ & $\begin{array}{r}0508 \\
(202)\end{array}$ & $\begin{array}{l}0.040 \\
(0.08)\end{array}$ & $\begin{array}{r}-0.261 \\
(0.47)\end{array}$ & $\begin{array}{l}-0.884 \\
(1.58)\end{array}$ & $\begin{array}{r}1736 \\
(3.09)\end{array}$ & $\begin{array}{l}1,291 \\
(2,12)\end{array}$ & $\begin{array}{r}0.216 \\
(0.38)\end{array}$ & $\begin{array}{r}0.204 \\
(0.74)\end{array}$ & 7.47 & 201 & 4.44 \\
\hline M1A & GNP & $\begin{array}{l}1.458 \\
(9.53)\end{array}$ & $\begin{array}{l}-0.661 \\
(2.61)\end{array}$ & $\begin{array}{l}0.048 \\
(0.19)\end{array}$ & $\begin{array}{r}0.119 \\
(0.76)\end{array}$ & $\begin{array}{r}0.025 \\
(0.26)\end{array}$ & $\begin{array}{r}0.050 \\
(0.40)\end{array}$ & $\begin{array}{l}0.097 \\
(0.78)\end{array}$ & $\begin{array}{r}0,226 \\
(1,81)\end{array}$ & $\begin{array}{r}-0.321 \\
(2.53)\end{array}$ & $\begin{array}{r}0.032 \\
(0.25)\end{array}$ & $\begin{array}{r}0.192 \\
(1.53)\end{array}$ & $\begin{array}{l}0.096 \\
(1.14)\end{array}$ & 5.47 & 1.81 & 154 \\
\hline M1B & GNP & $\begin{array}{r}1.484 \\
(9.85)\end{array}$ & $\begin{array}{r}0,634 \\
(250)\end{array}$ & $\begin{array}{r}0.037 \\
(0.14)\end{array}$ & $\begin{array}{l}0.125 \\
(0.82)\end{array}$ & $\begin{array}{l}0.018 \\
(0.20)\end{array}$ & $\begin{array}{l}0.062 \\
(0.52)\end{array}$ & $\begin{array}{l}0.055 \\
(0.46)\end{array}$ & $\begin{array}{l}0.176 \\
(1.48)\end{array}$ & $\begin{array}{l}0.295 \\
(2.46)\end{array}$ & $\begin{array}{r}0.226 \\
(0.21)\end{array}$ & $\begin{array}{r}0.226 \\
(1.88)\end{array}$ & $\begin{array}{l}0.114 \\
(1.41)\end{array}$ & 5.23 & 1.82 & 136 \\
\hline$M 2$ & GNP & $\begin{array}{r}1784 \\
(13,68)\end{array}$ & $\begin{array}{r}-0,993 \\
(3.71)\end{array}$ & $\begin{array}{r}0,320 \\
(1,19)\end{array}$ & $\begin{array}{l}0,105 \\
(0,74)\end{array}$ & $\begin{array}{l}-0.186 \\
(2.08)\end{array}$ & $\begin{array}{r}0076 \\
(0.66)\end{array}$ & $\begin{array}{r}0,030 \\
(0.26)\end{array}$ & $\begin{array}{r}0.034 \\
(0.30)\end{array}$ & $\begin{array}{r}-0.127 \\
(1,11)\end{array}$ & $\begin{array}{l}0.078 \\
(0.69)\end{array}$ & $\begin{array}{r}0.024 \\
(0,21)\end{array}$ & $\begin{array}{r}0.056 \\
(0.70)\end{array}$ & 5.06 & 1.99 & 012 \\
\hline M3 & GNP & $\begin{array}{r}1917 \\
(1481)\end{array}$ & $\begin{array}{r}-1.139 \\
(4.04)\end{array}$ & $\begin{array}{r}0.169 \\
(059)\end{array}$ & $\begin{array}{r}0.042 \\
(0.29)\end{array}$ & $\begin{array}{r}-0,088 \\
(1,00)\end{array}$ & $\begin{array}{r}0.060 \\
(0.50)\end{array}$ & $\begin{array}{r}-0,010 \\
(0,06)\end{array}$ & $\begin{array}{r}0.003 \\
(0.02)\end{array}$ & $\begin{array}{l}0,007 \\
(0,06)\end{array}$ & $\begin{array}{l}0.023 \\
(0.20)\end{array}$ & $\begin{array}{l}0.020 \\
(0.17)\end{array}$ & $\begin{array}{r}0.082 \\
(1.04)\end{array}$ & 528 & 1.96 & 0.35 \\
\hline$L$ & GNP & $\begin{array}{r}1796 \\
(13,62)\end{array}$ & $\begin{array}{l}0,842 \\
(316)\end{array}$ & $\begin{array}{r}0.014 \\
(0.05)\end{array}$ & $\begin{array}{r}0,030 \\
(0,20)\end{array}$ & $\begin{array}{l}0.033 \\
(0.50)\end{array}$ & $\begin{array}{r}0.037 \\
(0.43)\end{array}$ & $\begin{array}{l}0,073 \\
(0.84)\end{array}$ & $\begin{array}{l}0,104 \\
(1,22)\end{array}$ & $\begin{array}{l}0,128 \\
(1,47)\end{array}$ & $\begin{array}{l}0.026 \\
(0.30)\end{array}$ & $\begin{array}{l}0.071 \\
(0.84)\end{array}$ & $\begin{array}{l}0.009 \\
(0.16)\end{array}$ & 3.81 & 1.98 & 0.67 \\
\hline
\end{tabular}

Notes. All equations neluded a constant tem, 1 inear trend variable and three seasonal dummy variables, Absolute value of t-statistics appear in parentheses. Because the $R^{2}$ exceds 0,99 in every instance, only the standard error of the estimating equation is reported D. W is the Durbin-Watson statistic Critical valies for the Fstatistic are $F(s, 1) 2.82$ ( percent) and 210 ( 5 percent) 
The upper section of table 1 reports the results of testing the hypothesis that money is exogenous to (causes) GNP. The Durbin-Watson (D.W.) statistic shows no first-order serial correlation. ${ }^{16}$ The $\mathrm{F}$ statistics in the last column of table 1 test the joint significance of all the lag terms $\left(\beta_{j} s\right)$ for the different monetary variables, given lagged GNP. These F-statistics indicate that for the monetary aggregates $\mathrm{M} 1 \mathrm{~A}$ and $\mathrm{M} 1 \mathrm{~B}$, the hypothesis that money is exogenous to GNP cannot be rejected at the 5 percent significance level, At the 1 percent level of significance, the hypothesis cannot be rejected for the M2, M3 and $\mathrm{L}$ aggregates. These results thus indicate that money, when defined as M1A, M1B, M2, M3 or L, is statistically exogenous to GNP at high levels of significance.

Showing that the lagged money variables are significant as a group, however, does not preclude the possibility of bidirectional causality (GNP also is exogenous to money). To test for this, a second set of regressions is estimated. This group of regressions employs the different monetary measures as the dependent variables and lagged values of GNP as independent variables. These regressions, reported in the lower section of table $I$, are used to test the null hypothesis that GNP is exogenous to (causes) money.

The F-statistics reported in the lower-half of table 1 indicate that lagged GNP does not significantly explain movements in the various money measures, once lagged money is accounted for. Not only are they all well below acceptable critical values, but few of the individual coefficients on lagged GNP achieve statistical significance. Thus, the results reported in table 1 support the contention that there is unidirectional causation from money to GNP for the $\mathrm{M} 1 \mathrm{~A}, \mathrm{M} 1 \mathrm{~B}, \mathrm{M} 2$, M3 and L monetary measures.

To further investigate the econometric relationship between GNP and money, the Sims test procedures are implemented. Regression estimates for the Sims test are presented in table $2{ }^{17}$ Because future observations are required for the Sims test, the sample

16The D.W. statistic is not appropriate when the regression includes a lagged dependent variable. In ach regression reported in table 1 , however, the Durbin h-statistic could not be calculated. As a check, the residuals were calculated from each regression and used in estimating a second and fourth order autoregressive process (see footnote 17 ). The results from these tests support the contention in the text that no significant serial correlation exists.

17"The reported k-value in table 2 is the $k$ used to "whiten" the data, Some comments on the technique used to whiten the data in order that the Sims test can be used are in order. Preliminary estimates using the simple filter process period ends in II/1979. In each regression, four future and eight past values of the independent variable are used. The upper half of table 2 reports the results for the test that money is exogenous to GNP while the lower section reports those for the test that GNP is exogenous to money. A comparison of these two sets of regressions reveals an appreciable difference. The difference is the general insignificance of the estimated coefficients on future money in contrast to the relatively large number of statistically significant coefficients on future GNP. Indeed, this is precisely the outcome to be expected if money is exogenous to (causes) GNP.

Another interesting feature of the regression results is the pattern of the estimated coefficients on the future observations. The general pattern for the $\alpha(-4)$ to $\alpha(0)$ terms in the upper part of table 2 suggests an increasing influence of money on GNP over the first two quarters, followed by a decline in its influence over the next two quarters. This patterm is consistent with that found in studies examining the lag structure between GNP and money via reduced-form equations. ${ }^{18}$ In contrast, the future coefficients reported in the lower half of table 2 (the regressions used to test the hypothesis that GNP is exogenous to money) show no regular pattern.

The F-statistics pertinent to Sims' exogeneity test

employed in the Cranger tests revealed that the residuals were highly serially correlated. Because the F-tests used in the exogeneity tests are inappropriate in the presence of serial correlation, the following iterative procedure was used to remove serial correlation. Assuming that the serial correlation is not of order greater than two, the second-order filter $(1-\mathrm{kL})^{2}$ (where $0<k<1$ and $\mathrm{X}_{\mathrm{t}} \mathrm{L}^{\mathrm{i}} \equiv \mathrm{X}_{\mathrm{t}-1}$ ) was used to prefitter the data. The relevant regression is estmated with future and past values of the independent variable pres. ent and some initial value of $k$. The residuals from this regression are calculated and examined for autoregressive characteristics. This is accomplished by estimating the equations

(A) Resid $(t)=a_{0}+\sum_{i=1}^{n} b_{1} \operatorname{Resid}(t-i)+v_{1}(t)$

and

(B) $\operatorname{Resid}(t)=a_{i}^{i}+\sum_{i=1}^{4} b_{i} \operatorname{Resid}(t-i)+v_{2}(t)$,

where Resid is the estimated residual and $v_{1}(t)$ and $v_{2}(t)$ are error structures assumed to possess classical properties. The test for serial correlation, then, involves using the standard $F$-statistic to test for the significance of the $b_{1}$ and $b_{i}$ coefficients. If the calculated F-value exceeds the 5 percent critical value, another value of $k$ is chosen and the entire process is repeated. The final value of $k$ used to transform the data is that value which yields statistically insignificant F-statistics from both equations $A$ and $B$. This procedure is described in Y. P. Mehra, "Is Money Exogenous in MoneyDemand Equations," Joutnal of Political Economy (April 1978), pp. 211-28.

18See, for example, Carlson and Hein, "Monetary Aggregates as Monetary Indicators." 


\section{Table 2}

\section{Regression Results for the Sims Test}

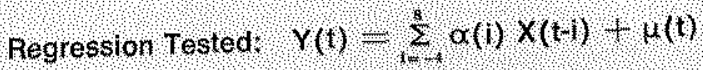

\begin{tabular}{|c|c|c|c|c|c|c|c|c|c|c|c|c|c|c|c|c|}
\hline & & & ( 31 & & & & $\begin{array}{c}\text { Sample } \\
a(1)\end{array}$ & $\begin{array}{l}\text { riod: } 111 \\
\alpha(2)\end{array}$ & $\begin{array}{l}961-\mid 1 / 19 \\
\alpha(3)\end{array}$ & $a_{a(4)}$ & $\alpha(5)$ & $\alpha(6)$ & $\alpha(7)$ & $a(8)$ & SE $\times 10^{-8}$ & $\mathrm{ow} / \mathrm{k}$ \\
\hline U1A & GNP & $-0,143$ & 0.080 & 0.148 & 0.214 & & 0.055 & -0.007 & $-0,082$ & $\begin{array}{l}0.034 \\
10.47)\end{array}$ & $\begin{array}{l}-0,128 \\
(1,72)\end{array}$ & $\begin{array}{r}-0,098 \\
(1,37)\end{array}$ & $\begin{array}{r}0.130 \\
(1,78)\end{array}$ & $\begin{array}{c}0,098 \\
(1,32)\end{array}$ & 4.41 & $\begin{array}{l}1.52 \\
0.6\end{array}$ \\
\hline MIB & GNP & $(2: 09)$ & $(1.09)$ & $\begin{array}{l}(2.14) \\
0.165\end{array}$ & $\begin{array}{l}(3.09) \\
0.215\end{array}$ & 0,172 & 0.076 & $\begin{array}{c}0.11) \\
0.031\end{array}$ & $\begin{array}{c}(1.48) \\
-0.015 \\
(0.24)\end{array}$ & $\begin{array}{r}10.47 \\
0.050 \\
(0.75)\end{array}$ & $\begin{array}{l}0.127 \\
(1.85)\end{array}$ & $\begin{array}{l}-0.081 \\
(1.23)\end{array}$ & $\begin{array}{l}0.159 \\
(2.35)\end{array}$ & $\begin{array}{r}-0.068 \\
(0.99)\end{array}$ & 4.33 & $\begin{array}{l}1.64 \\
0.6\end{array}$ \\
\hline m2 & GNP & $\begin{array}{l}(2.57) \\
-0.067\end{array}$ & $\begin{array}{l}(1.22) \\
0.161\end{array}$ & $\begin{array}{l}(2.57) \\
0.232\end{array}$ & $\begin{array}{r}(3,35) \\
0.313\end{array}$ & $\begin{array}{l}(2.63) \\
0.203\end{array}$ & $\left(\begin{array}{l}1,7) \\
0.054\end{array}\right.$ & $\begin{array}{r}(0.49) \\
-0.025 \\
(0.35)\end{array}$ & $\begin{array}{c}0.003 \\
(0.04)\end{array}$ & $\begin{array}{l}0.015 \\
(0.20)\end{array}$ & $\frac{0.126}{(1.59)}$ & $\begin{array}{l}-0.061 \\
(0.77)\end{array}$ & $\begin{array}{l}0,018 \\
(0,23)\end{array}$ & $\frac{0.079}{(1,07)}$ & 4.64 & $\begin{array}{l}1.70 \\
0.8\end{array}$ \\
\hline M3 & GNP & $\begin{array}{l}(0.93) \\
-0.006 \\
(0.08)\end{array}$ & $\begin{array}{l}(1,98) \\
0.127\end{array}$ & 0.231 & $\begin{array}{c}0.297 \\
(3.53)\end{array}$ & $\begin{array}{l}0.226 \\
(2.67)\end{array}$ & $\begin{array}{l}(0.7) \\
0.073 \\
0.90)\end{array}$ & $\begin{array}{l}0.006 \\
(0.08)\end{array}$ & $\begin{array}{c}0.010 \\
(0.13)\end{array}$ & $\begin{array}{l}-0.042 \\
(0.51)\end{array}$ & $\begin{array}{r}-0.070 \\
(0.79)\end{array}$ & $\begin{array}{l}-0,040 \\
(0,46)\end{array}$ & $\begin{array}{r}-0.073 \\
(0.82)\end{array}$ & $\begin{array}{l}0.023 \\
(0.28)\end{array}$ & 6.14 & $\begin{array}{l}1.55 \\
0.8\end{array}$ \\
\hline$L$ & GNP & $\begin{array}{r}(0.08) \\
0.050 \\
(0.97)\end{array}$ & $\begin{array}{l}(1.41) \\
0,070 \\
(1.21)\end{array}$ & $\begin{array}{r}0.172 \\
(3.10)\end{array}$ & $\begin{array}{r}0.231 \\
(4.27)\end{array}$ & $\begin{array}{l}0.223 \\
(4.11)\end{array}$ & $(0,160)$ & $\begin{array}{l}0.438 \\
(2.75)\end{array}$ & $\begin{array}{r}0.075 \\
(1.42)\end{array}$ & $\begin{array}{l}0.102 \\
(1.89)\end{array}$ & $\begin{array}{r}-0.005 \\
(0.09)\end{array}$ & $\begin{array}{l}0.013 \\
(0.23)\end{array}$ & $\begin{array}{r}0.039 \\
(0.69)\end{array}$ & $\begin{array}{l}0.043 \\
(0.82)\end{array}$ & 3.29 & $\begin{array}{l}1.89 \\
0.8\end{array}$ \\
\hline GNP & MIA & $\begin{array}{c}0.386 \\
(1.80)\end{array}$ & $\begin{array}{c}0.486 \\
(2.01)\end{array}$ & $\begin{array}{c}0.175 \\
(0.74)\end{array}$ & $\begin{array}{l}0.061 \\
(0.26)\end{array}$ & $\begin{array}{l}0.632 \\
(2.59)\end{array}$ & $\begin{array}{r}0.005 \\
(0.02)\end{array}$ & $\begin{array}{c}0,363 \\
(1,36)\end{array}$ & $\begin{array}{c}0.467 \\
(1.81)\end{array}$ & $\begin{array}{l}0.094 \\
(0.37)\end{array}$ & $\begin{array}{l}0.153 \\
(0.60)\end{array}$ & $\begin{array}{c}0,020 \\
(0,07)\end{array}$ & $\begin{array}{l}0,037 \\
(0.15)\end{array}$ & $\begin{array}{l}0,131 \\
(0,58)\end{array}$ & 8.24 & $\begin{array}{l}1.92 \\
0.6\end{array}$ \\
\hline GNP. & M1B & $\begin{array}{c}0.547 \\
(257)\end{array}$ & $\begin{array}{c}0,406 \\
(1,70)\end{array}$ & $\begin{array}{c}0.186 \\
(0.80)\end{array}$ & $\begin{array}{r}0.037 \\
(0.16)\end{array}$ & $\begin{array}{r}0.724 \\
(2.89)\end{array}$ & $\begin{array}{l}-0.026 \\
(0.10)\end{array}$ & $\begin{array}{l}0.256 \\
(1.00)\end{array}$ & $\begin{array}{c}0,400 \\
(1,62)\end{array}$ & $\begin{array}{l}0.108 \\
(0.44)\end{array}$ & $\begin{array}{l}-0.156 \\
(0.64)\end{array}$ & $\begin{array}{r}0.051 \\
(0.21)\end{array}$ & $\begin{array}{l}0,028 \\
(0,12)\end{array}$ & $\begin{array}{c}0.138 \\
(0.64)\end{array}$ & 7.76 & $\begin{array}{l}220 \\
0.6\end{array}$ \\
\hline GNP & M2 & $\begin{array}{l}0.049 \\
(0.24)\end{array}$ & $\begin{array}{l}-0,099 \\
(0.32)\end{array}$ & $(0,015)$ & -0.014 & $\begin{array}{r}0.205 \\
(0.62)\end{array}$ & $\begin{array}{r}0.363 \\
(1,09)\end{array}$ & $\begin{array}{c}0.081 \\
(0.24)\end{array}$ & $\begin{array}{r}0.412 \\
(1.19)\end{array}$ & $\begin{array}{l}-0.378 \\
(1.13)\end{array}$ & $\begin{array}{l}0,146 \\
(0.45)\end{array}$ & $\begin{array}{l}0.042 \\
(0.13)\end{array}$ & $\begin{array}{l}0.178 \\
(0.55)\end{array}$ & $\begin{array}{l}0.64 \\
(0,76)\end{array}$ & 7.83 & $\begin{array}{l}1.74 \\
0.4\end{array}$ \\
\hline GNP & M3 & $\begin{array}{l}0.105 \\
(0.49)\end{array}$ & $\begin{array}{l}0.213 \\
(0.72)\end{array}$ & $\begin{array}{l}-0.063 \\
(0.21)\end{array}$ & $\begin{array}{c}-0.110 \\
(0.37)\end{array}$ & $\begin{array}{l}0.225 \\
(0.76)\end{array}$ & $\begin{array}{l}0,208 \\
(072)\end{array}$ & $\begin{array}{l}0.778 \\
(0.61)\end{array}$ & $\begin{array}{r}0.092 \\
(0.31)\end{array}$ & $\begin{array}{c}0.394 \\
(1,34)\end{array}$ & $\begin{array}{l}0.685 \\
(2.30)\end{array}$ & $\begin{array}{l}0.436 \\
(1.46)\end{array}$ & $\begin{array}{c}0.234 \\
(0.79)\end{array}$ & $\begin{array}{c}0.087 \\
(0.42)\end{array}$ & 8.44 & $\begin{array}{l}1.68 \\
0.5\end{array}$ \\
\hline GNP & ᄂ & $\begin{array}{c}0.024 \\
(0.09)\end{array}$ & $\begin{array}{l}0.226 \\
(0.58)\end{array}$ & $\begin{array}{l}0.194 \\
(0.50)\end{array}$ & $\begin{array}{l}0.006 \\
(0.02)\end{array}$ & $\begin{array}{c}0.404 \\
(1.02)\end{array}$ & $\begin{array}{r}0.165 \\
(0.42)\end{array}$ & $\begin{array}{l}0.249 \\
(0.62)\end{array}$ & $\begin{array}{c}0.130 \\
(0.33)\end{array}$ & $\begin{array}{l}0.711 \\
(1.74)\end{array}$ & $\begin{array}{r}0.622 \\
(1.50)\end{array}$ & $\begin{array}{c}-0,265 \\
(0.63)\end{array}$ & $\begin{array}{l}0.041 \\
(0.10)\end{array}$ & $\begin{array}{r}0.197 \\
(0,74)\end{array}$ & 7.83 & $\begin{array}{l}1.61 \\
0.4\end{array}$ \\
\hline
\end{tabular}

ided a constart to

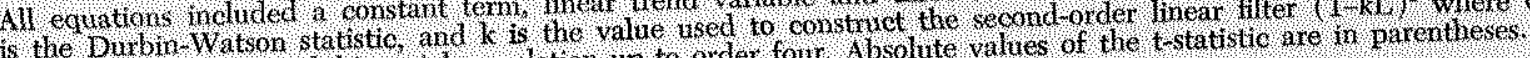

resiluals that do not exhbit serial correlation up to order 
Table 3

\section{Sims Test Results}

\begin{tabular}{|c|c|c|}
\hline $\begin{array}{l}\text { Dependent } \\
\text { variable }\end{array}$ & $\begin{array}{l}\text { Independent } \\
\text { varlable }\end{array}$ & F-statistic \\
\hline MAA & GNP & 4.33 \\
\hline MAB & GNP & 5.58 \\
\hline M2 & GNP & 5.72 \\
\hline M3 & GNP & 3.70 \\
\hline$L$ & GNP & 5.69 \\
\hline $\mathrm{GNP}$ & MIA & 1.65 \\
\hline GNP & $\mathrm{MAB}$ & 2,28 \\
\hline GNP & $M 2$ & 0.09 \\
\hline GNP & M3 & 0.15 \\
\hline GNP & L & 0.14 \\
\hline
\end{tabular}

Notes Tho calculated $\mathrm{F}$-statistic is pertinent to testing the joint significance of the future values in the regressions reported in table 2 . Critical $F$-values $(4,54)$ are. 254 ( 5 percent) and 3.68 ( 1 percent).

are reported in table 3 . To reiterate, these tests investigate the joint significance of the future coefficients. If the set of future coefficients is significantly different from zero, then the $\mathrm{Y}$ variable (the dependent variable) is exogenous to the $\mathrm{X}$ variable (the independent variable). Based on standard levels of statistical significance, the results in table 3 suggest that every monetary aggregate is exogenous to nominal GNP; the hypothesis that money is exogenous to GNP cannot be rejected at the 5 percent significance level. In contrast, the notion that GNP is exogenous to money is not supported by the results of the Sims test; the calculated F-statistics are below the $\widetilde{5}$ percent level of significance. Thus, the Sims and Granger test results agree; the new monetary aggregates are exogenous with respect to nominal GNP.19

197he tests used in this article are useful in detecting statistical exogeneity, not empirical correlations between GNP and the different monetary aggregates, per se. Because of the relatively nondefinitive nature of the results in selecting a

\section{CONCLUSION}

Increased emphasis has been placed on the growth of the monetary aggregates in the formulation and implementation of monetary policy. In February 1980, the Board of Governors of the Federal Reserve System announced major redefinitions of existing monetary aggregates. Crucial to selecting an appropriate monetary measure to be used in policymaking is its exogeneity with respect to the goal variable. This article has empirically investigated the relationship between the new monetary aggregates and nominal GNP by using the exogeneity tests proposed by Granger and Sims. Based on quarterly observations for the period III/1961-II/1980, the results reported here indicate that each of the new monetary aggregates is statistically exogenous to GNP. This supports the belief that control of the money stock is important in influencing movements in GNP.

Although the evidence in this article does not permit the selection of one of the new monetary aggregates as the "best" indicator of monetary actions, it does form a foundation upon which a selection can be made. In this regard, further study into the issues of controllability and predictability of monetary aggregates is warranted.

"best" indicator, it was felt that a useful exercise would be to briefly examine the isste of predictability. This was done by regressing the compounded annual rate of growth of $G N P(Y)$ on the compounded annual growth rates of money (M) in its different defritions and high-employment government expenditures $(E)$. The form of the regression equation is

$\dot{\mathrm{X}}_{\mathrm{t}}=\mathrm{c}+\sum_{\mathrm{t}=0}^{\mathrm{p}} \mathrm{m}_{1} \dot{\mathrm{M}}_{\mathrm{t}-\mathrm{i}}+\sum_{\mathrm{i}=0}^{\mathrm{k}} \mathrm{e}_{\mathrm{i}} \dot{\mathrm{E}}_{\mathrm{t}-\mathrm{t}}+\varepsilon_{\mathrm{t}}$,

where the lag lengths $f$ and g are each equal to four and $\varepsilon_{\mathrm{t}}$ is a random errer tem. Following Carson and Hein, this relationship is estimated using ordinary least squares. The sample period was III/1961-11/1980.

Comparing the adjusted $\mathrm{R}^{\mathrm{t}} \mathrm{s}$ obtained by using the MIA, MIB, M2, 13 and $L$ monetary agregates indicates that MlB explains movements in the growth rates of GNP better than the other aggregates. For comparison's sake, the monetary aggregates and their corresponding $\overline{\mathrm{R}}^{2} \mathrm{~s}$ are: MIA $(0.36) ; \mathrm{MLB}(0.39) ; \mathrm{M} 2(0.23) ; \mathrm{M} 3(0.21) ;$ and $\mathrm{L}(0.33)$. Given the results from the exogeneity tests, this evidence further supports the choice of MIB as the most likely monetary indicator from the aggregates examined.

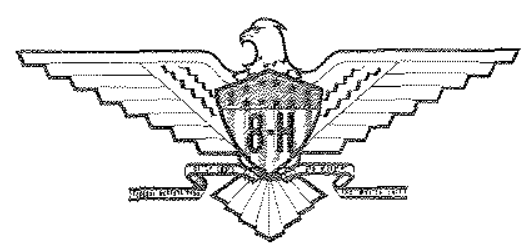

